UDC 371 (477.42) (09)

http://doi.org/10.21272/mmi.2018.4-23

JEL Classification: M14, M100, M140

Frank J. Cavico,

Professor, Nova Southeastern University, USA

Bahaudin G. Mujtaba,

Professor, Nova Southeastern University, USA

\title{
TEACHING LAW, ETHICS, AND SOCIAL RESPONSIBILITY IN A SCHOOL OF BUSINESS: A VALUE-DRIVEN APPROACH TO LEADERSHIP AND SUSTAINABILITY
}

Abstract. Human beings are not perfect decision-makers and therefore need formal and informal development opportunities. History has shown that very intelligent professionals in the technical, as well as philosophical fields, have made huge mistakes that have been very costly, i. e. the Chernobyl disaster. Doctors have operated on the wrong leg of patients and consequently, the patients have lost their good leg. Engineers have designed buildings and bridges that have collapsed because of their mistakes or oversights. In the past, philosophers and scientists have stated abstracts theories, which have been proven wrong. For example, whoever said that the earth is flat probably did not go very high; yet this was an accepted statement, which proved to be wrong. Therefore, it is very possible that as human beings even the most intelligent of us could make mistakes. For some, this may need to be a paradigm shift while for others this is already an accepted belief. Consequently, as human beings, we need training and education for making more effective and ethical decisions. The study of doing what is right can be approached from a philosophical perspective in ethics courses. This paper provides practical suggestions for creating and teaching a stand-alone ethics course along with the values of legality, morality, social responsibility, and sustainability for future professionals, managers, and leaders in business and society. The paper explains ethical egoism, relativism, utilitarianism, and Kantian ethics. This research methodology is rooted in "best practices" as well as fifty years of personal teaching experiences of the authors. As such, all the content and suggestions have been applied, practised, and perfected over several decades. As such, the suggestions and recommendations are best practices that can be integrated into existing curriculums by faculty members who are asked to teach ethics and other philosophical classes. Faculty who are teaching ethics courses can benefit from the suggestions provided by the authors, particularly by reflecting on the twenty-three specific "teaching tips" included throughout the article.

Keywords: ethics, morality, teaching ethics and morality, utilitarianism, Kantian ethics, relativism, egoism, social responsibility, sustainability.

Introduction. Modern educators are often criticized for not teaching values, ethics, morality, and legal challenges that graduates might face in the workplace (Lynn, 2010). Many college curricula do not have stand-alone courses in ethics, but instead, such philosophical discussions of ethics are supposedly "weaved" into the curriculum. As a result, the achievement of such competencies does not always get measured as part of the formal outcomes-assessment programs. Realistically, the discerning educator knows that what does not get measured will eventually be ignored (Mujtaba, 2014). As such, ethics, morality, social responsibility, law, and sustainability topics should be taught both as stand-alone courses, as well as be covered throughout the curriculum, in order to develop ethically and legally literate graduates who can be effective professionals, managers, and leaders (Lynn, 2010; Lieux \& Winquist, 1991).

This article is about practices in teaching ethics, law, social responsibility, and sustainability. The concepts and "best practices" come from decades of teaching a values-based course, "The Values of Legality, Morality, and Social Responsibility of Business," that the authors developed at their school of business. These seminal values of law, ethics, social responsibility, as well as sustainability, are addressed, explained, and illustrated in a required MBA law and ethics course. Yet, it is, and must be, emphasized to the students that these subject matters will arise in several of their other courses (by means of case studies, teamwork, group exercises, analytical papers, simulations, discussion) as well as, of

Cite as: Cavico, F. J., \& Mujtaba, B. G. (2018). Teaching Law, Ethics, and Social Responsibility in a School of Business: A Value-Driven Approach to Leadership and Sustainability. Marketing and Management of Innovations, 4, 263-281 http://doi.org/10.21272/mmi.2018.4-23 
course, in the "real world." In addition, and not to belabour the point, but it cannot be emphasized enough to the students that these are values, which the students will take into, be exposed to, and be challenged by in the "real world."

The literature on Ethics. Ethics, or the study of what constitutes right or wrong, is a subject that touches many aspects of one's life privately and professionally. On a daily basis, each individual makes decisions based on his or her own judgment of what is considered to be right according to one's unique ethical constitution. However, not all standards, values and ethical systems are universal in nature, which creates complexity when working in a heterogeneous society or workforce. What one person considers to be right may not be what another person considers to be right or fair based on his or her upbringing and value system. These differences, in some cases, may extend across races, ethnicities, and sub-cultures that exist within most countries. In addition, ethics also exist in groups that may be entirely different from the ethics of the individuals that comprise the group (Mujtaba, 2014; Mujtaba, 2009). Studies have shown that these differences may also exist within the same race, ethnicity, and culture - these differences have been attributed or related to an individual's level of education and age (Mujtaba, McCartney, Cavico, and DiPaolo, 1999). Overall, the ethics one adopts, during his/her socialization process in the society, can be influenced by many people and groups of people. First, unlike the color of one's hair and eyes or most other physical characteristics, one's personal ethics is not something that an individual is born with as it can be taught and learned (Lynn, 2010; Lieux \& Winquist, 1991; Kaifi, 2012; Pelletier and Mujtaba, 2015; Teowkul, Seributra, Sangkaworn, Jivasantikarn, Denvilai, and Mujtaba, 2009; Yooyen, Pirani, and Mujtaba, 2011; Zareen, Razzaq and Mujtaba, 2015). In addition to learning how to survive, one learns many things from one's parents and caretakers. Second, the source of one's ethical and moral development is usually not limited to one's family or caretakers. Many of the ethical lessons people learn throughout the years are the result of experiences with other sources of information such as one's peers, teachers, mentors, heroes, media, etc.

Of-course, being put in a position of having to stand for good causes along with great role models tends to make for a good learning experience. Such experiential learning, according to experts, is one of the most common means through which an individual develops ethically (xxx). A third aspect that has been important in the development of people's personal values, morals, and ethics is personal reflection and critical thinking skills. Values, morals, and ethics can be influenced by family and institutions, but it is up to the individual to understand, adopt and use them effectively in decision making. Through critical thinking, an individual evaluates each challenge and value to determine if they have practical applications to the individual's life (xxx). For instance, it is not uncommon for many individuals during their early years to be taught negative values and beliefs such as racism towards others who are different from them, fighting, winning at all cost, and hatred from the various sources of information in the society. Sometimes, these beliefs are passed down from one generation to the next generation without anyone ever questioning their validity. Without critical thinking, these beliefs would be passed on to future generations indefinitely unless there are transitional people who think for themselves and match their beliefs with what seems fair and accurate based on their current environment and systems in place. Many people are taught different beliefs; however, through critical thinking, individuals can recognize the weaknesses and strengths of each belief for themselves. Therefore, critical thinking skills and ethics go hand and hand and individuals can make decisions for themselves in terms of what seems right and what ethical theories should be used for different situations.

Ethics literature confirms that ethics topics along with moral philosophies and legal subject matters should be formally taught to students (Yeung; 2004; Yeung and Pine, 2003; Whitney, 1989; Vallen and Casado, 2000; Upchurch, 1998; Stevens and Brownwell, 2000; March and Schmidgall, 1999; Lynn, Howey, and Combrink, 2007; Lundberg, 1994; Lin, Martin, and Cobanoglu, 2002). Current and past literature on teaching ethics have demonstrated that the content, teaching strategies, and "best practices" 
can provide sample lesson plans to effectively impart knowledge of ethics and morality to students (Costello, 1994; Enghagen, 1990; George, 2008; Hegarty, 1990; Jaszay, 2002; Khan and McCleary, 1996; Kovaleski, 2004; Lieux and Wingquist, 1991). Many academicians and researchers have gone beyond just talking and researching about the importance of ethics to actually teaching it (Mujtaba, 2003; Mujtaba, 1997ab; Mujtaba, 1996; Huang, Mujtaba, Cavico, and Sims, 2006; Mujtaba and Sims, 2006). Teaching effectively requires research, planning, experimentation, and continuous improvement (Kaifi, Mujtaba and William, 2009; Al-Abbadi, Alkhateeb, Khanfar, Mujtaba, \& Latif, 2009; Mujtaba and Gibson, 2007; Mujtaba and Kennedy, 2005; Mujtaba, Preziosi and Mujtaba, 2004; Mujtaba and Mujtaba, 2004).

In this paper, based on the experiences of the authors (Cavico and Mujtaba; 2016; Cavico and Mujtaba, 2014; Cavico and Mujtaba, 2013; Cavico, Mujtaba, Nonet, Rimanoczy, and Samuel, 2015; Lynn, 2010; Mujtaba, 2014; Mujtaba and McCartney, 2007), we offer best practices in creating a course on ethics, morals, law, social responsibility, and sustainability to help college students become effective decision-makers for their organizations and society.

Methodology. It has been said that experience can be one of the best educators as long as one reflects on the past and learns from it. As continuous learners, we should learn from our experiences, as well as from what others have learned over time based on their successes and failures.

The research methodology for this applied paper is rooted in "best practices" as well as over fifty years of management as well as personal teaching experiences of the authors. The authors have taught ethics courses for undergraduate and graduate students, conducted ethics workshops with corporate managers, and have published written five books and over 100 journal articles based on their research regarding morality and ethical decision-making based on age, gender, management experience, ethics training, education, and other such variables. As such, some of the content and suggestions presented here have been either tested empirically or were applied, practised, and perfected over several decades. Our hope is that these suggestions and recommendations for effectively teaching ethics and morality are best practices that can be quickly integrated into existing curriculums by faculty members who teach ethics and social responsibility courses. Therefore, the rest of the paper provides various elements related to ethics, morality, law, social responsibility, and sustainability along with our recommendations for teaching tips.

Findings and Discussion. Based on practical experiences of teaching and conducting workshops on the topic of ethics, we have found that it is always best to start with some common definitions so everyone can have a clear understanding of the terminologies. Having an understanding of values, ethics and morals are essential for all students and leaders if they are to live with honour and glory in the modern workplace. The following are some of the basic definitions linked to ethics and effective decision making:

- values are core beliefs or desires that guide or motivate one's attitude and actions. What one values drive his/her behaviour. Some people value honesty or truthfulness in all situations while others value loyalty to a higher degree in certain situations;

- ethics is the branch of philosophy that theoretically, logically, and rationally determines right from wrong, good from bad, moral from immoral, and just from unjust actions, conducts, and behaviour. Some people define ethics as doing what you say you would do or walking the talk;

- business ethics deals with the creation and application of moral standards in the business environment. Ethics establishes the rules and standards that govern the moral behaviour of individuals and groups. It also distinguishes between right and wrong conducts. It involves honest consideration to underlying motive, to possible potential harm, and to congruency with established values and rules;

- applied ethics refers to moral conclusions based on rules, standards, Codes of ethics, and models that help guide decisions;

- morals are judgments, standards, and rules of good conduct in the society. They guide people toward permissible behaviour with regard to basic values.

Most people think that "ethics" is about differentiating right from wrong. However, most adults know it 

Approach to Leadership and Sustainability

is a little more difficult than that when applied in daily activities where competing "right" dilemmas require support.

Furthermore, it should be underscored that the values of ethics, morality, law, social responsibility, and sustainability are not merely ones to be addressed in any particular course; and, consequently, these values are neither separate subjects nor academic "silos"; rather, they are values that are integrated into other programs, activities, and courses at a university or college. The students need to be reminded that they are in a college or school of business; that is, the faculty, administration, and staff have created an integrated academic institution and not just a series of separate and discrete courses. One important objective of the students will thus be to integrate subject matters from all their courses, especially in a strategy course, which typically is the business student's "capstone" course or experience. The ultimate goals are to achieve academically, as well as in business, good, efficacious, decision-making and accordingly to attain excellence in results.

Teaching Tip 1: Perhaps the reader's academic institution is a signatory on the United Nations' Principles of Responsible Management Education, which is a "compact" with other schools as well as companies and government agencies in order to transform management education by emphasizing social and environmental responsibility and sustainability (by means of teaching, research, dialogues, and partnerships in private and public sector. And if so, the Principles, as well as their importance, should be presented to and discussed with the students. Similarly, the reader's school may also have taken the United Nations Climate Pledge, based on American Campus Act, wherein institutions promise to reduce their "carbon footprint," reduce greenhouse gasses and conserve energy and water. See with the students what your institution is doing in these areas and perhaps what it could and should be doing.

All universities, colleges, and schools have the vision, mission, and value statements. Typically, like that of the authors, they stress Academic Excellence, being Student-Centered, Ethics and Integrity, Innovation, Opportunity, Scholarship and Research, Community Service, Diversity and Inclusion, Leadership, and Teamwork. These core policy statements should be presented to and discussed with the students, and they must be shown how the course under examination herein helps to fulfil and illustrate these key values. All schools also have an Academic Honesty Policy, which the students must be told forcefully that the school takes very seriously. However, it is best, especially in a course with an ethics component, not to dwell on the "legalistic" and punitive aspects of the policy; rather, in the opinion of the authors, the students must be taught that the goal is to establish a culture of honesty and integrity at the institution. Integrity, honesty, and ethics belongs not only in this course, class work, and classroom but in all their courses and classes and in the workplace and "wider-world."

Teaching Tip 2: In the course under examination herein the professor should naturally mention the policy and review some basic definitions, for example of plagiarism and cheating. And it must be underscored for the students during their whole program that if there is any doubt as to what is required of, or prohibited to, a student regarding school work the student must always check with his/her professor. Naturally tell the students to make sure that they "give credit where credit is due"; but particularly in a graduate or upper-level course also tell them not to over-rely on references and footnotes; as such, explain that beginning students merely report whereas upper-level and graduate students also analyze, comment, criticize, and reason to conclusions.

Teaching Tip 3: Get the students to think about creating a Student Journal; that is, impress upon them the importance of creating a journal from what you learned in this class and their other classes, especially about real-world value creation. Then, upon graduation, they can convert their journal into an article academic or ever for the "popular press." Such an endeavour would surely impress a potential employer or investor. A suggestion for a title might be: "Top Ten Things I Learned in My Graduate Business Program/MBA to Create Value."

"Good" Decision-making. The foundation for any law, ethics, and social responsibility type, of 
course, is decision-making by the student when he or she attains a management or equivalent position in a company or organization. That decision-making must be "good," that is sound and efficacious and thus will achieve real-world results. Impress on the students that the purpose of their coursework at the university, college, or school is to help them make better decisions in the real world and thus to add value to their firms and organizations.

Teaching Tip 4 - Emphasize to the students that their courses at the school are not separate and discrete subject matters, they are not "academic silos." Rather, the courses build on one another; they can be integrated; and knowledge from one course can be extrapolated to other courses; and as such the students can take a broader and more strategic approach to solve problems and taking actions (with a strategy course typically being the final capstone course in a school of business). For example, the professor could point out that a substantial part of anti-trust law, especially regarding mergers and monopolization, depends on the definition of a "market" and market division and segmentation, and that market terminology and definitions, so critical in anti-trust law will be learned in the students' marketing classes. Also, it could be pointed out to the students that other subjects covered in a law class will be covered in other courses too, for example, insider trading in a finance class or bribery in an international business law course.

Teaching Tip 5 - Encourage the students, particularly graduate researchers, to prepare a journal based on key aspects of their learning from their various courses. Perhaps the journal could be called "Ways to Create Value based on my MBA Program." Then further encourage the students to develop an article, even if "just" for the "popular press," based on their journal entries. Such an article naturally would give the student and school some good publicity and help the student's career.

The prime objective of the course under discussion herein is to inculcate to the student that the decisions must be "good"; yet not "merely" from a practical perspective; but they also must be good in the sense of complying with the values of legality, morality, and social responsibility. The idea is to "drill" the students into a value-driven mindset, and as such to impress on the students to always ask and answer when contemplating a decision or action: "Is it legal, is it moral, and what should a socially responsible organization be doing"? Legality, morality, and social responsibility, therefore, emerge as the seminal values in the course. As such, it is necessary to briefly discuss, differentiate, and illustrate "values."

Values - Intrinsic v. Extrinsic. Values are things that possess worth; they are valuable! However, to complicate things a bit the philosophers say that values can be intrinsic, also called terminal, or "merely" extrinsic, also called instrumental (and please note the quotation marks). If a value is deemed to be intrinsic it is viewed as good in-and-of-itself; no other explanation, rationale, or justification need be given for it. The principal example given of an intrinsic value is happiness; that is, it is just and simply good to be happy - period. Another example is aesthetics, that is, the ability to appreciate beauty. But if a value is merely deemed to be instrumental (which is the authors' preferred usage) the value is not necessarily good and valuable in-and-of-itself, but rather because it is a means, tool, or instrument to produce something else of value. The principal example is money, which is good and valuable because you can buy a lot of "neat stuff" with money (so who says "money can't buy you happiness). Another example is the value of being nice and polite to people (even if you do not like people) because being nice and polite is an instrument to you having friends, associates, team-players, and good employees.

Teaching Tip 6: Discuss with the students and have them provide examples of what values they think are terminal as opposed to being merely extrinsic. Then say to the students to consider this dichotomy when you cover the values of legality, morality, ethics, social responsibility, and sustainability with them. That is, are these values intrinsic or are they merely instrumental? And perhaps if the latter emphasize to the students that if a value is only instrumental do not discard it because it can still serve as a valuable tool to produce something else of value - for themselves, their businesses, or organizations.

The Value of Legality. Assuming there is a foundation of good and sound decision-making the first 
value to address is whether the contemplated action is legal, which perforce brings us into the realm of the law. As noted, the subject matters discussed herein are related, and thus could, and in the authors' opinion should be taught in one course - an upper-level undergraduate or graduate level course. It is not the intention of the authors to explicate all the legal elements to such a class, suffice-it-to-say that the concentration should be on government regulation of business subjects, such as securities law, anti-trust law, and civil rights laws, which were laws promulgated to eliminate, prohibit, and punish unethical business and employment practices. Assuming morality and ethics are part of the course we would stress that the moral "gaps" in the law should be discussed; that is, emphasize those areas where a practice may be legal but nevertheless may be immoral based on ethics. For example, cite the working conditions by foreign suppliers of U.S. firms who obtain their products in countries with very weak worker protection and environmental laws (or perhaps where there is some law "on-the-books" but it is not enforced, perhaps because of the bribery of host country government inspectors and regulators). Moreover, emphasizing the "lines" the law draws (and also point out none too clearly), for example, under securities law between illegal insider trading and potentially legal trading on inside information (by the "lucky" who fortuitously and propitiously overhear something). Another example would be the line the Foreign Corrupt Practices Act draws between illegal bribes to foreign government officials and mere "goodwill" gifts as well as payments related to the demonstration and explanation of a firms' products and services, such as reimbursement for transportation, lodging, and meals, as well as entertainment.

Teaching Tip 7: Use as a case study the "oldie-but-goodie case of the bribery scandal involving the Olympics hosted by Salt Lake City and the subsequent prosecution of two of the Salt Lake City Organizing Committee principals for violating the Foreign Corrupt Practices Act. And note the perhaps "surprise ending" and the role that social responsibility played in the ultimate resolution of the case.

Another way to illustrate the "intersection" of law and ethics would be to show when immoral behaviour can trigger legal liability. The best example would be pursuant to monopolization law under Section 2 of the Sherman Anti-trust Act, where presuming a company has a monopoly in a given "market" (which is an interesting as well as important issue in-and-of-itself, and one which brings in the field of marketing, and which thus shows the students how subject matters are not "academic silos" but are, and can and should be, integrated to resolve issues) the issue is what type of wrongful conduct is required to turn that company and its "mere" monopoly into a "monopolizing" company. As such, illegal conduct, such as bribery, pricefixing, or for that matter arson, will do; but what is most interesting and thought-provoking under monopolization law is that conduct which is legal but is construed as abusive, predatory, and/or unethical is also "wrongful."

Teaching Tip 8: Discuss with the students and ask for illustrations, and explanations thereof, of conduct which is legal but unethical in the context of monopolization law; and better yet, discuss with the students where and what the line is between abusive, predatory, and unethical conduct and mere "tough" and "hard-hitting" legal competition.

The Value of Morality. Beyond and above the value of legality is the value of morality, which is based on ethics; of course, ethics is a branch of philosophy, like logic and metaphysics (the study of ultimate reality). Within the field of ethics are various ethical theories which one can use to reach moral conclusions. As such, it is important to note and to stress to the students that there is a difference between morality, the conclusion as to what is right or wrong, or good or bad, and how one arrived at that conclusion. Philosophically, one ascertains a moral conclusion by applying ethical theories and principles, that is, the intellectual framework, that one uses to reason to moral conclusions. So, one needs ethics to arrive at morals! The problem is, of course, is that there are several ethical theories, and the two relatively modern ones in Western Civilization - Utilitarianism and Kantian ethics - are diametrically opposed, and there is no "Supreme Court of Ethics" to give us an answer as to which theory, or for that matter any ethical theory, is the true and correct one. Yet that variety of theories gives one the opportunity to choose and apply 
certain ethical theories, perhaps in a "sophisticated" way. In Western Civilization (not the only one for sure but the one that the authors teaching ethics is premised on) there are the following major ethical theories: Ethical Egoism, Ethical Emotism, Ethical Relativism, Legal Positivism, Utilitarianism, and Kantian ethics. Although it is beyond the purposes of this article to provide an ethics treatise the authors would like to explicate some of the basic principles of these theories and then show how they could be taught in an applied fashion in an upper-level college or graduate law and ethics class.

There is, clearly today, an expectation that business will act not "merely" legally but also morally, which perforce brings one into ethics, which is the branch of philosophy with the theories and principles that one uses to reason to moral decisions, morality, morals, and moral "rules." The goal is to impart a keen awareness of the moral component to "good" business decision-making and then to teach the aforementioned main ethical theories in Western Civilization and how to apply them to determine if business, even if acting legally, is acting morally based on ethics. However, it also must be inculcated to the students that there is a critical distinction between "Right Thinking," that is, knowledge of traditional ethical theories, vs. "Right Answers," that is, in the "real-world" there may be not absolutely "right" answers and they may even be two "right" but contradictory moral answers because of the application of different ethical theories.

Ethical Egoism. Ethical Egoism is an ethical theory first propounded by the ancient Greeks, were originally attributed to the philosophic school of the Sophists in $5^{\text {th }}$ century B.C. The modern, relatively speaking, the proponent of this ethical theory is the $18^{\text {th }}$ century English economist Adam Smith. The basic tenet of ethical egoism maintains that it is moral to advance one's self-interest; and thus in a business context, it is moral to make money. That is, an action that advances one's self-interest is a moral one; and, conversely, an action that is detrimental to one's self-interest is an immoral one. As per Adam Smith's rationale, if everyone seeks to advance their self-interest not only will they benefit but society and the general welfare will benefit too as there will be more efficient and effective production and distribution of goods and services. Yet there are some constraints on the doctrine. First, is to take long-term perspective as to maximize one's self-interest, and thus be willing to undergo some short-term sacrifice, expense, and effort in order to maximize one's own long-term greater good. Second, generally, it is preferable to treat people well, to make them part of one's team, in essence, to co-op them. And why should one be so "nice"? Because it is in one's long-term self-interest to have friends and allies as opposed to enemies. So, Adam Smith said, by all means, be selfish in the egoistic sense, but do so in a smart, prudent, and rational manner. That is, be an enlightened ethical egoist, but advance oneself, learn useful knowledge and skills, and become wealthy and powerful. Ethical Egoism, therefore, and this should be appealing to the business students, defines morality as advancing one's self-interest; in essence, it is moral to make money (but, remember to take a long-term perspective as to maximizing your self-interest, and thus also be willing to undergo some short-term expense and effort, as well as to treat people well). Yet it is all about you!

Teaching Tip 9: It would be a fun and intellectually stimulating exercise to review with the students some of the writings of the ancient Greek Sophists and Machiavelli. The Sophists were total relativists; they did not believe in the intrinsic, absolute, and objective truth to anything; but they did believe that certain subject matters, including morality, ethics, justice, and religion, had instrumental value, that is, they were tools to advance one's self-interest. Moreover, if the students may have "princely" ambitions perhaps the professor could bring in a few choice quotes from a more "modern" Sophist, the Renaissance political philosopher, Niccolo Machiavelli, such as, one knows how to be good but one to be successful must learn how not to be good and use that knowledge or refrain from using it as necessity requires. Although Machiavelli wrote for a more political audience ask the students if he was right, that is, today, can one be a successful politician, and extrapolate that question to one becoming a "big-tine" CEO without having to do at some point the occasional, traditional, bad and immoral act (which under Machiavelli's "sophisticated" reasoning is now a good and virtuous act. 

Approach to Leadership and Sustainability

Ethical Relativism. When in Rome, do as the Romans do." Surely the students have heard of this famous statement, though perhaps not understanding its ethical implications. As such, that old saying is a good introduction to the ethical theory of Ethical Relativism, which actually harkens back before the Romans to a later group of the Sophists in ancient Greece. The key aspect of this ethical theory is that morality is determined by societal beliefs, mores, and precepts. That is, what a society believes is moral for that society is, in fact, moral for that society. Consequently, one does not need to be a philosopher to determine morality; rather, one needs "sharp" eyes-and-ears to discern what the moral standards are "on the ground" in a particular society. This theory, therefore, emerges as the international business person's ethical "best friend" since one "merely" must get educated as to the prevailing moral norms in the host country. Then one just must conform to and adopt those norms and one will be acting morally in that country. Naturally, one does not want to get educated the "hard way" by gratuitously and foolishly contravening some local moral norm; so the astute business person will always check with the local appropriate local chamber of commerce representing his or her country, ask the expatriate community for advice, and always follow the perhaps best counsel to "let the locals deal with the locals" as they know the local norms and "system" and thus know what has to be done to get the deal done. Also, one must be cognizant and make sure the students know, that there may be a superseding legal principle to ethical relativism.

Of course, two societies can disagree as to moral norms, for example, as to funeral practices for burying vs. cremating the dead, or, on a more pleasant note, swimsuit required vs. swimsuit optional beaches. Yet, a weakness of this ethical theory is that there is no arbitrating mechanism to say which country's or which society's moral beliefs are objectively and absolutely true and correct. But they are true and correct for that society, so one should merely confirm and adapt and be moral there and one should not be a "cultural imperialist" and consequently try to impose one's country's or society's moral views on another. So, if the Chinese do not have any moral qualms about the public execution of prisoners who have "voluntarily" donated their organs to the state, which then sells them to wealthy buyers, then why should you!

Teaching Tip 10: Ask the students, who hopefully come from diverse national and/or societal backgrounds about their own moral norms, especially regarding business practices and particularly regarding giving some "goodwill" gifts to higher level foreign government officials as well as some "tips" and "grease-money" to lower level officials in order to get a deal or to process the shipment of goods or required "paperwork." Stress to the students that these practices if considered in the host country to be customary and appropriate are moral actions in that county or society. Yet also emphasize to the students that the ethical theory of Ethical Relativism and conforming to local norms (that is, "everyone is doing it" is not a legal defence, for example, to bribery pursuant to the Foreign Corrupt Practices Act. And remind them that JP Morgan Bank settled bribery charges and paid a fine of over $\$ 200$ million for allegedly bribing high-level Communist party officials in China who were in charge of state-run companies in order to secure lucrative consulting contracts by hiring their sons and daughters pursuant to a program called (and one must admit honestly and openly) the Sons \& Daughters Program.

Utilitarianism. Utilitarianism is an ethical theory created by the $18^{\text {th }}$ English philosophers and social reformers, Jeremy Bentham and John Stuart Mill. The theory is a consequentialist ethical theory; that is, morality is determined by focusing in on all the stakeholders (also called "constituent groups) affected by the action. There is a predictive element to this ethical theory; that one must predict consequences as they affect each discrete stakeholder group, including society as a whole. Ethical Egoism is, of course, a consequentialist ethical theory too, but plainly with Utilitarianism, the scope of analysis is much, much broader than merely oneself. Predicting the consequences of an action is obviously a challenging task, but the Utilitarians say, first, to use one's "common storehouse of knowledge" and to use "history as a guide." Second, one needs to look for probabilities of occurrences as well as the reasonably foreseeable 
consequences of putting an action into effect. Finally, one must attempt to measure and weight consequences, first, for each stakeholder group and then among all the stakeholders. Accordingly, if there are predominantly good consequences the action is a moral action; and conversely, if there are predominant negative consequences the action is an immoral one. The goal of the Utilitarians was to seek to promote happiness, satisfaction, pleasure, but note that since the "ends justify the means" there can be some painful consequences produced but overall since there is more good an action can be deemed moral. However, one problem with this theory is that the "ends can justify means"; that is if there is more good than bad the action is moral even though there are some consequences that cause pain, suffering, and unhappiness consistently to a specific stakeholder group.

Teaching Tip 11: Mergers are an excellent example of Utilitarian analysis since there is never a paucity of mergers in the news, the students are familiar with mergers, perhaps too familiar if they were on the "losing side," and a merger can be examined as to the effects on each stakeholder group affected and the pleasure or pain resulting from the merger. Moreover, the merger can be examined pursuant to the merger test in the Clayton Act for the legal analysis. Finally, the merger can be examined from the standpoint of social responsibility and sustainability in the sense of what should the giant merged company, assuming government approval, be doing for society and the environment.

Teaching Tip 12: Foreign, exploitative, literally "stinkin"” "sweat-shops" are a good vehicle for some controversial Utilitarian analysis, since, assuming they are legal, such a sweat-shop may produce the greater good for all the stakeholders affected even though the working conditions are (legally) deplorable. The goods produced, say sports regalia or sneakers, resulting in a lot of money for a lot of people. Remind the students that under Utilitarianism the "ends justify the means"; and then discuss with them all the stakeholders affected and the good and bad produced by the "good" goods produced in the exploitative sweat-shop. Finally, remind the students that there is one more major ethical theory in Western Civilization to cover, and which must be applied to any moral controversy, and one diametrically opposed to Utilitarianism - and that is Kantian ethics.

Kantian Ethics. Kantian ethical theory is based on the moral philosophy of the $18^{\text {th }}$-century German philosopher and teacher, Immanuel Kant. Disregard consequences in determining morality said Kant, and rather focus on the application of a formal test which Kant called the Categorical Imperative. "Categorical" because declared Kant, this is the supreme and absolute ethical principle; and "Imperative" because one must at times command oneself, despite contrary self-interest, to do what the Categorical Imperative impels one to do; that is, to do the moral action regardless of consequences, even to oneself. By ethical reasoning from the Categorical, Imperative one will logically be able to ascertain the moral course of action (Cavico and Mujtaba, 2013). Of course, one can clearly see the major conflict in secular-based ethics in Western Civilization since the Utilitarians focus on the consequences of an action in determining morality; whereas Kant says to disregard consequences and instead apply the Categorical Imperative. For the Utilitarians, the "ends justify the means"; but for Kant, the means itself must be moral as per the Categorical Imperative.

There are two main tests to the Categorical Imperative. One is called the Kingdom of Ends test. Pursuant to this test an action is moral if it treats people with dignity and respect and as a worthwhile means; as such, if an action is demeaning and disrespectful to people and if it treats them like a tool, instrument, or means, even to a greater good overall, the action is immoral. Another test of the Categorical is called the Agent-Receiver test. In essence, it is the Golden Rule ("Do unto others what you would have them do unto you.") made secular by Kant. Pursuant to this test, an action is moral if one as a rational being and one did not know that one would be the giver, that is, the agent, of the action, or its receiver would be willing to have the action done. And if one would not want to be on the "receiving end" of the action, then it is immoral. Kantian ethics, therefore, as opposed to Utilitarianism, demands that we disregard the consequences of an action, and rather focus on the application of a formal test to the action 
to determine morality. Consequently, the moral conflict that emerges in Western ethics centres on whether one is a Utilitarian or Kantian, or perhaps one takes a more "sophisticated" view of ethics.

Teaching Tip 13: Bribery of foreign government officials can be the basis of a thought-provoking case study for the students to apply Ethical Egoism, Ethical Relativism, Utilitarianism, and Kantian ethics. The case student should involve a U.S. business person, whose company is the lowest bidder for a foreign government project, and whose product is a good deal for the host country government and its people, but this business person is surprised when the foreign government official who has to "sign-off" on the project requests before signing an additional "commission fee" of several thousand U.S. dollars, and where the foreign government official "assures" the U.S. business person that these fees are customary in his or her country. Consequently, let the students analyze if the "payment" is an illegal bribe, and, even if so, is it moral or immoral under the major ethical theories mentioned herein.

Ethics and Leadership. One goal of the university, college, or school very likely will be to develop the students into leaders in business, the public sector, the professions and otherwise. As such, an objective of the course under discussion herein is to help with that noble endeavour. Philosophically as well as practically the ethical challenge for a leader today is to formulate actions that advance the selfinterest of his or her organization (Ethical Egoism), are culturally competent (Ethical Relativism), and achieve the "greater good" (Utilitarianism) by striving for "win-win" scenarios for all affected stakeholders, but without demeaning or disrespecting any stakeholders (Kantian Ethics). This is not an easy hurdle to overcome, but it is critical to the long-term success of a person individually and especially as the leader of an organization.

The role of the leader is to "know the way, show the way, and go the way." That is, the leader is to know the way and then to educate decision-makers as to what is in their long-term self-interest; to show the way, that is, to demonstrate to top management, board of directors, shareholders, and others that acting morally as well as legally will benefit the organization; and finally to go and lead the way to the successful implementation of "good," legal, and moral decisions. Concomitantly the role of a leader is to create at one's organization a culture of ethics that fosters and supports moral behaviour as well as to establish a personal and corporate/organizational reputation for integrity and trust (because once a reputation for trust is lost, it is very, very difficult to get it back.

The role of a true leader may be to change a corporate culture. The role of a leader also may be to object if an action is legal but immoral; as such, the leader must practice the "stand your ground" strategy; and remember that effective and ethical leaders can disagree without being disagreeable. Accordingly, as a true leader have the strength of character, courage, and conviction to do the right thing and not do the wrong thing, and "blow the whistle" on wrongdoing when necessary.

Teaching Tips 14: Remind the students of the Wells Fargo Bank fake account scandal and the Volkswagen deceptive emissions scandal. How could such scandals happen? How could these giant global companies have a culture of tolerance for law-breaking or, worse, encouragement to law-breaking? And now how can these companies regain a reputation for honesty, integrity, and ethics. Discuss these issues with the class! Maybe trust can be regained by total honesty, transparency, acceptance of responsibility, empathy for victims, identification of the harm, remedial measures instituted, promises of follow-through, and heartfelt apologies (plus some generous financial redress to the aggrieved parties). Yet, in the authors' humble opinion, once a reputation for morality and ethics is lost it is very, very hard to get it back.

The preceding ethics examination was designed to help the professor inculcate to the students the following: what ethics is, the difference between morality and ethics, the need to base moral conclusions on reasoning from ethical theories, and the role of a leader in ensuring the moral behaviour of his or her firm. These ethical theories, however, are designed primarily to help us determine when we affirmatively act to act morally, that is, to do no moral harm. Yet, the next ethics question to answer is if, and when, one 
has a moral duty to act, that is, to help, to aid, and to rescue. To answer this question, it is first necessary to note and to explain the distinction between legal misfeasance and legal nonfeasance.

Legal Misfeasance v. Nonfeasance. The law, going back to Old English common law days, makes a critical distinction between Legal Misfeasance and Legal Nonfeasance. This key distinction must be made clear to the students. Legal misfeasance means that one has affirmatively acted and in so doing one has violated some law - criminal law (thereby "breaching the King's Peace") and/or civil law (such as the tort of negligence or intentional torts such as the invasion of privacy. Moreover, one action can be both a crime and a civil wrong, such as assault and battery, which is a criminal wrong as well as an intentional tort. Misfeasance, moreover, should not be confused with its "cousin" malfeasance, which is misfeasance in the public sector, such as embezzlement, bribery, or nepotism by government officials. The point to misfeasance is that when one acts one must do so in accordance with the law and not commit an intentional legal wrong, criminal or civil, or the civil wrong of the tort of negligence by acting in a careless, unreasonable, and imprudent manner. That is the "price one pays" for living in a nice peaceable Kingdom under King William, King Henry I, and King Henry II (when these common law principles were first developed).

Yet with misfeasance, there is an "actor," that is, someone is acting, doing something, and not doing it "right." The problem arises when one does nothing, that is, one does not act at all. Thus, the concomitant critical issue arises as to when one has a duty to act and thus when one can be liable for not acting. To answer these questions reference must be made to the doctrine of Legal Nonfeasance.

Legal Nonfeasance means not acting; and the general rule, again harkening back to Old English days, is that there is no liability for not acting. Consequently, as a general rule (but with lots of exceptions) there is no legal duty and no legal liability for not acting, not aiding, not helping, and not rescuing a person, and not avoiding a peril. The old cases dealt with drowning and pursuant to the nonfeasance doctrine one is not under any legal duty to rescue a drowning victim, even if one is a very good swimmer. Let 'em drown, or let em' bleed, and do not worry about any lawsuits from the estates of the victims. One may not be a "good" person not to attempt a rescue or some aid, but one is a legal person. Legal Nonfeasance, as emphasized, is a general rule. There are many exceptions developed through the years by case law and by statutes (which supersede the common law principle).

Teaching Tip 15: See what examples the students the students came come up with as examples to Nonfeasance, where one is legally obligated to act and to rescue, for example, when one is under contract, like a nurse or lifeguard on duty, or when a health-care professional or certain university personnel have a duty to report child or elder abuse, or when common carriers and innkeepers have a duty to warn of hazards on their property. It also could be pointed out that some health care professionals by virtue of their code of ethics, for example, nurses pursuant to the nursing Code of Ethics and the Florence Nightingale Oath who feel they have a moral obligation to render aid even if not on duty.

Legislative bodies, moreover, have promulgated Good Samaritan statutes, to encourage people to rescue even if they do not have a legal duty to do so. Typically, these statutes do not absolve the rescuer of all legal responsibility as the statutes characteristically say that one still must rescue in a reasonable and prudent manner under the circumstances, with the situation differing between helping an elderly person who has fallen on the sidewalk and attempting to extricate a person from a burning car.

Teaching Tip 16: Discuss with the students and seek examples and explanations of the type of conduct, for example, otherwise intentional tort conduct, that would be exonerated by a Good Samaritan statute. Also, discuss with the students the type of circumstances that would be so critical that the situation would excuse certain types of intentional conduct as well as affect the degree of negligence in an attempted rescue.

The overall conclusion to Legal Nonfeasance, however, is that unless an exception applies, one does not have a legal duty to act or to rescue, and one may not be motivated to help by a Good Samaritan 
statute. Yet then the question arises as to whether one has a moral duty to act, to rescue, to help, and to aid; and answering that question perforce brings one into the realm of ethics. And, conveniently, we have an ethical principle, called the Ethical Principle of Last Resort, to tell us when we have a moral duty to act.

The Ethical Principle of Last Resort. First and foremost, it must be emphasized to the students that the Ethical Principle of Last Resort is an ethical principle that deals with moral duties to act; and as such no one is going to be sued for violating an ethical principle unless in so doing some legal precept is violated. There is no legal duty to be moral; there is "just" a legal duty to be legal. Yet pursuant to the Ethical Principle of Last Resort one has a moral duty to act, to aid, to help, and to rescue when five elements are present:

1.Need (which is the obvious predicate as someone needs help).

2.Proximity (that is, sensibly, that the would-be rescuer is nearby).

3.Capability (derived from the Kantian principle that "ought implies can": that is, if you say to a person that he or she should do something there is a logical inference that they can physically do it).

4.Last resort (the essence of the principle in that the would-be rescuer is the last realistic alternative to avoid the peril or harm).

5.Finally that the aiding or rescuing would not cause harm equal to or greater than the original peril.

So, the typical example is a drowning situation where one who is a very good swimmer rescues a drowning victim even if under no legal duty to do so because the good swimmer pursuant to the Last Resort principle would be morally obligated to do so. However, if a large shark (actually any shark!) appears by the victim one would not be morally obligated to do rescue due to the potential of harm to oneself. Of course, regardless of the threat of harm by the shark one does rescue the drowning victim than one is beyond Last Resort and had been elevated into the more stratified realm of being a Moral Hero. Conversely, if there is no harm and Last Resort is operative and one does not rescue that one is acting immorally and acting immorally pursuant to an established ethical principle. But one will not be sued legally due to the Nonfeasance principle absent any legal duty to act. And one may not care that he or she is accused of being an immoral person by not rescuing, but that type of nefarious reputation may have other, though non-legal, adverse consequences in society and business.

Teaching Tips 17- Discuss with your students when a business might, arguably at least, have a moral duty to help, aid, and rescue. The typical examples deal with drowning, so do not accept a drowning at a company picnic as an acceptable example! Better illustrations might be the big pharmaceutical companies giving AIDS drugs for free or at the cost to poor nations or Wal-Mart bringing in aid supplies to New Orleans after hurricane Katrina or similarly Royal Caribbean Cruise Lines doing the same in Puerto Rico after hurricanes Irma and Maria. Were these businesses really the "last resort"? What happened to governments and international agencies?

The Value of Social Responsibility. Above and beyond the value of legality and morality is the value of social responsibility. Accordingly, another challenge for the business leader today is to ensure that his or her firm is acting in a socially responsible manner. Moreover, social responsibility is a societal expectation today above and beyond the law as well as morality and ethics. Business is expected to be a "socially responsible" entity, that is, a good "corporate citizen," though there may be neither a legal obligation nor a moral duty to do so. One problem though is that the definition is a broad and allencompassing one. "Social Responsibility" thus can include the following components:

- charity and philanthropic endeavours and civic and community activities (called by the Wall Street Journal, and a bit pejoratively in the authors' opinion, "old school" social responsibility), which is the traditional model of social responsibility. An interesting example is the offer by the city of Rome, Italy to businesses in the Sponsor-a-Roman-Ruin campaign, wherein a company can provide money to city for the update of an ancient or old ruin, for example, the trendy apparel company, Fendi, now is sponsoring the Trevi Fountain (getting some good and well-deserved publicity); 
- sustainability as a means in the form of environmental conservation and protection and clean and renewable energy production via solar and wind, for example, the Hilton Hotel using artistic wind turbines to produce energy. This form of social and environmental responsibility is also known as "going green," "3 P's: People, Planet, Profits," or the "Triple Bottom Line" (Economic Prosperity, Environmental Stewardship, and Social Responsibility);

- social Entrepreneurship, for example, the creation of hydrogen-fuel-cell-powered batteries for forklifts which now are used at Amazon and Walmart. Another interesting global example is the Mutiara Trash Bank in Makassar, Indonesia, which helps the environment and introduces poor people to banking and finance by taking their "deposits" in recyclable trash, paying them money into their newly opened bank accounts, and then turning over the trash to local government for recycling.

Teaching Tip 18: Perhaps you as a professor have students who are interested in the environment and in being successful entrepreneurs. See what other examples of socially responsible and sustainable products and services you can come up with. Moreover, depending on the funding on your school perhaps a formal program could be instituted wherein the school could give grants or microloans to the students to develop their "green" ideas, all under the supervision of the faculty, of course.

Social Responsibility and Sustainability Investing, that is, Mutual Fund investments in sustainable products and services, for example, solar and wind power; desalinization plants; anti-pollution devices. The goal is to develop a sustainability and social responsibility portfolio of "green" investments, as well as taking a long-term strategy. Such investments will "do good" and the investors and fund principals also will "do well"; accordingly, improving the world and getting some positive returns surely will appeal to the students, especially the finance-oriented students.

- "green bonds," which are debt securities issued by government agencies and banks in developing countries to finance infrastructure projects, e.g., water and sewerage treatment plants, affordable housing, hospitals, and alternative energy projects;

- social responsibility and sustainability auditing and certification (which surely will appeal to the accounting students) as per the standards promulgated by the accounting standards board.

Teaching Tip 19: Do not usurp the "jurisdiction" of your accounting faculty colleagues but review briefly the definition and standards used by the accountants, and then impressed on the students how prestigious and important it would be for a firm to obtain the imprimatur or endorsement of the accounting profession. That is if one is "certified" as "green," efficient, and effective when it comes to the environment and energy then one can extrapolate that one's firm is efficient and effective in all its endeavours.

Social responsibility, therefore, including sustainability as an environmental means, is emerging as a major topic in academia and for the business community and society and thus for business schools and business students for the coming decades; accordingly, the students as future business leaders must be cognizant of these issues and must be able to meet these challenges. "To be forewarned is to be forewarned," as the old maxim goes.

Consequently, some of these challenges to the business leader include:

- how much social responsibility should a firm engage in? The authors submit that the students should be advised that a firm should engage in the right, prudent, and moderate amount of social responsibility, according to the firm's financial condition. Accordingly, do not do too much, or too little. The idea is to attain a proper balance between profits and social responsibility.

Teaching Tips 20: Perhaps the examples of Ben \& Jerry's and British Petroleum's (BP) Sir John Browne could be used as examples of very socially responsible companies that went awry when too little attention was paid to other core values, such as the financial condition of the firm as per Ben and Jerry's and maintenance and safety as per BP.

What type of social responsibilities should a firm engage in? Again, the authors submit that the students should be advised that a firm should engage in activities tied to its image, brand, mission, 
products, and services. That is, emphasize a marketing and consumer-oriented approach to social responsibility. To illustrate, Home Depot is involved with Habitat for Humanity, Royal Caribbean (RC) is involved with Haiti, building schools and health clinics, and coincidentally RC has a port and private island in Labadee. Similarly, Starbucks is building schools and health clinics in Guatemala, where, again coincidentally, the company gets a great deal of its coffee. Carnival Cruise has a "social impact travel" brand where cruise passengers can volunteer for socially responsible activities on their port calls, for example, tutoring local children and helping to build schools. Mondelez International (the giant global snack food company, maker of Oreo cookies and Ritz crackers) has a Cocoa Life program as part of its social responsibility plan. The company works with more than 90,000 cocoa farmers in Ghana and the Ivory Coast and other countries to develop a sustainable network of cocoa for the future; each year the company send 15 employees, known as Joy Ambassadors, to help the farmers work on the projects and to improve the quality of life in their villages; the company is spending over $\$ 400$ million in a 10 year period. In return, the company gets a more robust and reliable supply chain of sustainably-sourced cocoa, employees who are excited and motivated, and the ability to market the company's social responsibility program to consumers.

Teaching Tip 21: Discuss with the students or perhaps have them do some research as to a company's social responsibility activities that are similarly tied to its products and/or services, values, mission, and brand. This assignment definitely should appeal to the marketing majors!

The result of such social responsibility is a smart, shrewd, and strategic social responsibility, which, in essence, is a marketing and sales approach to social responsibility. As such, remind the students that for many of them a Strategy course will be their academic capstone integrating course. So, their objective will be in that course and in the "real-world" to weave corporate social responsibility into their business strategy as opposed to keeping it a separate and unrelated function. The excellent result will be a good reputation (and deservedly so) for being a socially responsible firm (along with being a legal and moral entity too), plus the firm will gain a reputation for efficiency by being a smart and shrewd socially responsible firm; and accordingly the good reputation will benefit the company with customers, clients, shareholders, business and financial community, local community, and government, help to attract and retain talented employees, as well as bolster its supply chain. Of course, the business leader may have to convince the board of directors, CEO, CFO (especially), and shareholders that it is in the long-term self-interest of the company to be a socially responsible and sustainable one; but that is one aspect of leadership, that is, to show the way!

The rationale for being socially responsible, therefore, is our "old friend," Ethical Egoism; and that fact must be impressed on the students. They must be inculcated as to the instrumental worth of being a "socially responsible" organization. The advancement of the long-term self-interest of individual and firm plus a benefit to the community will occur from being socially responsible in the right manner and the right amount. Consequently, the students in their careers will be able to "do good," and they will "do well."

The Value of Sustainability. Another important value and component of the course tied to the law, ethics, and social responsibility is sustainability. At this time, there is no uniform interpretation of the word "sustainability." Some of the current definitions are as follows (Cavico and Mujtaba, 2016):

- from the United Nations (generally): Sustainability means an organization is taking care of people's present needs without compromising future generations;

- from the United Nations (in a business context): Sustainability means the company delivering longterm value in financial, environmental, ethical, social, and economic terms;

-from the Wall Street Journal: Sustainable companies are those that "incorporate environmental, social, corporate-governance practices into long-term corporate strategies; and note that typically corporate governance encompasses legal/regulatory and ethical/codes of ethics components;

- from the Accounting Standards Board: sustainability refers to environmental, social, and governance 
dimensions of a company's operation and performance; the objective is the management of a corporation's environmental and social impact in order to create long-term value;

- from the authors herein: Sustainability should be viewed as a MEANS in the form of environmental actions, conservation, protection, and "green" energy production) but also as an ENDS, that is, ensuring a sustainable planet for future generations). One example of sustainability is the aforementioned Hilton Hotel chain artistic wind turbines that produce "green" energy.

The United Nations also offers some advice to business leaders and business students, to wit: it is not plausible for any global company to exclude sustainability from its agenda, because there are now new and different expectations on the role and function of business in society; and business people must take heed of these expectations. Consequently, companies that do not take corporate social responsibility seriously these days do so at their own peril. Studies indicate that consumers and investors demand that companies be socially responsible and sustainable. Moreover, studies also indicate that consumers would be willing to pay more for products from companies that are socially and environmentally responsible. The rationales for acting in a sustainable manner would be not "just" to "save-the-planet" but to see sustainability as a tool to profitable employment and business opportunities (the latter now being called "social entrepreneurship") by solving social and environmental problems. Such an approach plainly should appeal to the job-seeking as well as the entrepreneurially minded student. (Remind the students that many companies, for example, Timberland, are only looking for applicants with education and training in social and environmental responsibility. Tell the students that they should position themselves for a job, career, or business in the "Green Economy.")

Teaching Tip 22: Have the students do a brief presentation on corporate social responsibility and sustainability by researching a company's website to see what the company is engaged in. Have the students see how a company itself defines these key terms and what they are doing in these areas. Then ask the students if they feel the company is in fact socially responsible and sustainable; and if not, what suggestions would the students offer. Yet, even if the company is a "good" one surely the student can come up with a couple of suggestions to make the company even more socially responsible and sustainable. Finally, have the student explain why the company should be engaged in these efforts.

Teaching Tips 23: Surely your university, college, and/or school has made a commitment to sustainability, for example, in university-wide sustainability committees, by your university participating in United Nations initiatives on sustainability, including UN Global Compact to promote sustainability (by schools, business, and government). Similarly, there very likely will be "green" campus organizations for students to promote and improve environmental and sustainability efforts and activities at the university and the local community, like recycling initiatives and water and energy conservation programs. Moreover, perhaps your university, college, or school has scholars-in-residence to help create sustainability programs, seminars, and courses as well as to work with faculty to integrate sustainability into the courses. Impress on the students the importance of taking advantage of all the sustainability as well as sustainability academic and practical initiatives offered. Getting involved and "going green" are not merely "academic" exercises, as the students, as well as the larger society and planet, will benefit.

The Egoistic Rationale for "Good" Conduct. The rationale for acting morally, which must be impressed on the students, is Ethical Egoism, that is, it is in the long-term advancement of self-interest of the students and the companies and organizations they lead to be a legal, moral, socially responsible, and sustainable entity. Principled leaders who possess integrity and fulfil their responsibilities and societal expectations will have firms that have good character AND as a result, these firms will do better financially in the longterm. Accordingly, the business student and soon-to-be business leader must always undergo the three values "drill" and thus when contemplating an action ask: Is it legal? Is it moral? And what should a socially responsible and sustainable company be doing?

Leadership and Values. Leadership, therefore, is an important topic for the students as our potential 
leaders in society. Considering their college-level academic career, and even more so for the graduate scholars, these students very likely will be our leaders in business, the professions, and the public sector. As emphasized herein, and as must be emphasized to the students, the leader must know the way, show the way, and lead/go the way. Self-awareness is a critical feature of leadership, that is, being cognizant of your own situation as well as the impact of your actions on others (as per Utilitarianism). A leader may need to apply new and varied approaches, ideas, solutions, and techniques to solve problems (especially with newer concepts and challenges such as social responsibility and sustainability). A leader must also be aware of his or her "blind spots"; that is, to be aware of your weaknesses, in the sense of what you do not do well or do not do at all. Yet the leader must know his or her strengths; and also be able to identify opportunities (e.g., for example by joining and eventually leading a company's social responsibility or sustainability committee). Most importantly, the leader must not be "blindsided" by weaknesses (e.g., being accused of acting immorally, or being accused of not being socially responsible and sustainable, though acting legally). However, a person may have hidden strengths, which he or she must become aware of, bring to light, and highlight (in the business world for the students to put on their resumes). For example, a student may already exhibit socially and environmentally responsible behaviour by volunteering in the community or joining a university "green" organization.

Leaders, of course, are expected to make sound business and public policy decisions and thus achieve excellence in results; also, they must be proactive; that is, the leader must be a "shaper" not a mere "reactor": The leader must anticipate challenges, thereby knowing the way, showing the way to solving them; and leading the way to implement solution. Moreover, it is of critical importance for the leader to embrace and demonstrate moral behaviour and to establish an organizational culture of morality and ethics. The students must be impressed that these are the challenges to business leaders today; these are the expectations that society has as to the proper conduct of business.

The societal expectations today are that business will act not "only" legally, but also morally, and then, especially when a business reaches a certain size and stature, act in a socially responsible and sustainable manner too. As such, business is expected to have a positive impact on society as a whole and the environment. The students, therefore, must be inculcated as to their responsibilities today, that is, that they must go "above and beyond" the law and act morally, and then go "above and beyond" morality and ethics to act in a socially responsible and sustainable manner. The leader, accordingly, must be prepared for these issues and challenges; the business leader must be concerned with not only the economic and legal performance of the company but also its moral and socially responsible performance.

Conclusion. As emphasized herein, and as must be emphasized to the students, today, there is an expectation that business will act legally, morally, and in a socially and environmentally responsible manner. Business students must be prepared for "real-world" challenges of being a business leader and ensuring that business acts accordingly. The business leader, therefore, must fulfil these expectations and meet these challenges in an effective and efficacious manner. The objective and rationale is sustainability as an end; that is, to achieve success and to be able to sustain that success for yourself, your company, your community, society as a whole, and for future generations and for the planet. The goal is to be a legal, ethical, socially responsible, and sustainable global business leader; to do well, and to make a positive contribution; and have a positive impact on your firm and its stakeholders, including the community, and society as a whole. And how do you achieve success? How do you sustain success? What is the Formula? The formula is to make sound decisions and to create and lead a legal, ethical, socially responsible, and sustainable enterprise! That is your mindset! Accordingly, to be successful to make good decisions and always ask and answer the following questions: Is it legal, moral, and what should a socially responsible and sustainable organization be doing? Future researchers should empirically survey practitioners to test if such a course in ethics and morality in the curriculum makes a statistically significant positive difference in the decision-making of professionals in the modern workplace. 
The objective of this article, the course in ethics, as well as the entire educational program, is to develop students into legal, ethical, socially responsible, and sustainable leaders and to be successful in their careers and professions. The greatest satisfaction of the authors as well as, we are sure, of the readers of this article, is the success of the students. Accordingly, offer highly relevant degrees and programs that put students on the path to successful careers. The authors and readers want them to realize their potential, especially their leadership potential, and to be successful and to be able to sustain that success over time. The authors trust that in this article they have made a modest contribution by presenting a course with legal, ethical, social responsibility, and sustainability components that will guide educators and ultimately contribute to the success of the students.

\section{References}

Al-Abbadi, I., Alkhateeb, F.M., Khanfar, N. M., Mujtaba, B. G., \& Latif, D. A., (2009). Pharmacy Students' Perceptions of the Teaching Evaluation Process in Jordan. Education, Business and Society: Contemporary Middle Eastern Issues, 2(3), 181-190.

Cavico, F. J. and Mujtaba, B. G. (2016). Developing a Legal, Ethical, and Socially Responsible Mindset for Sustainable Leadership. Davie, Florida: ILEAD Academy, LLC.

Cavico, F. J. and Mujtaba, B. G. (2014). Legal Challenges for the Global Manager and Entrepreneur. Dubuque, lowa: Kendall Hunt Publishing Company

Cavico, F. J. and Mujtaba, B. G. (2013). Business Ethics: The Moral Foundation for Effective Leadership, Management, and Entrepreneurship, 3d edition. Boston, Massachusetts: Pearson Custom Publishing.

Cavico, Frank J., Mujtaba, Bahaudin G., Nonet, G., Rimanoczy, Isabel, and Samuel, Marissa (2015). Developing a Legal, pp. 9-26.

Costello, T. (1994). Making the tough choices: Do you persevere, compromise or ignore? Cooking For Profit, 5(23), 13.

Enghagen, L. K. (1990). Teaching ethics in hospitality \& tourism education. Hospitality Research Journal, 14(2), 467-474.

George, R. T. (2008). Ethical perceptions of hospitality students and the discussion of ethical behavior. Journal of Hospitality \&

Tourism Education, 20(2), 16-22.

Hegarty, J. A. (1990). Ethics in hospitality education. International Journal of Hospitality Management, 9(2), 106-109.

Huang, C.; Mujtaba, G. B.; Cavico, F.; and Sims, R. L. (July 2006). Ethics and Executives: A Cross-Cultural Comparison of Japan, Taiwan, and the United States. International Business and Economics Research Journal, 5(7), 9-22.

Jaszay, C. (2002). Teaching ethics in hospitality programs. Journal of Hospitality \& Tourism Education, 14(3), 58-63.

Kaifi, Belal A. (2012). Organizational Behavior: Managing and Leading Organizations. Aeon Publishing Inc.: United States.

Kaifi, B, Muitaba, B. G., and William, A.A. (October 2009). Online college education for computer-savvy students: a study of perceptions and needs. Journal of College Teaching \& Learning, 6(6), 1-16.

Khan, M. M., \& McCleary, K. W. (1996). A proposed model for teaching ethics in hospitality. Hospitality \& Tourism Educator,

8(4), 7-11.

Kovaleski, D. (2004). Companies stay clean with ethics training. Corporate Meetings \& Incentives, 23(10), 22.

Lieux, E. M. \& Winquist, S. C. (1991). Instruction in writing combined with an introduction to ethics in a professional discipline.

Hospitality \& Tourism Educator, 3(2), 34-35.

Lin, J. M., Martin, L., \& Cobanoglu, C. (2002). Educators' perceptions of business ethics in hospitality. Journal of Teaching

in Travel \& Tourism, 2(3/4), 47

Lundberg, C. C. (1994). Topic paper: The views of future hospitality leaders on business ethics. Hospitality \& Tourism Educator, 6(2), 11-13.

Lynn, Christine (2010). Teaching Ethics with an Integrated Online Curriculum. Journal of Hospitality, Leisure, Sport and Tourism Education, 9(2), 123 - 129. Retrieved on October 26, 2018 from: https://docplayer.net/783092-Teaching-ethics-with-an-integratedonline-curriculum.html

Lynn, C., Howey, R., \& Combrink, T. (2007). Students' responses to ethical dilemmas. FIU Hospitality Review, 25(2), 1-9.

March, L. \& Schmidgall, R. J. (1999). Teaching legal and ethical issues: Where does tip reporting fit? Journal of Hospitality \&

Tourism Education, 11(2-3), 60-63.

Martin, L. J. (1998). Integrating ethics into the hospitality curriculum. Journal of Hospitality \& Tourism Education, 10(2), 22-25.

Muitaba, B. G. (2014). Managerial skills and practices for global leadership. ILEAD Academy: Florida.

Mujtaba, B. G., (2003). Ethical Implications of Employee Monitoring: What Leaders Should to Consider! Journal of Applied Management and Entrepreneurship, 8(3), 22-47. Available on: http://www.huizenga.nova.edu/jame/employeemonitoring.htm

Mujtaba, B. G., (1999). Cross Cultural Marketing Ethics: Literature Review and Training Suggestions. Journal of Global Competitiveness, 7(1), $235-251$.

Mujtaba, B. G., (1997a). Corporate Ethics Training Programs. Journal of Developments in Business Simulation and Experiential Learning, 24(1), 130-131. 
F. J. Cavico, B. G. Mujtaba. Teaching Law, Ethics, and Social Responsibility in a School of Business: a Value-Driven Approach to Leadership and Sustainability

Mujtaba, B. G., (1997b). Business Ethics Survey: A perspective from the retail industry. Journal of Developments in Business Simulation and Experiential Learning, 24(1), 186-187.

Mujtaba, B. G., (1996). Ethics and Morality in Business. Journal of Global Competitiveness (JGC), 4(1), 339-345.

Mujtaba, B. G., \& McCartney, T. (2007). Managing workplace stress and conflict amid change. Llumina Press: Florida.

Mujtaba, B. G., and Gibson, J. (2007). The creation and implementation of a formal faculty orientation and training program in higher education. Journal of College Teaching and Learning, 4(6), 17-24.

Mujtaba, B. G., and Kennedy, J. W. (2005). Facilitating Affectively to Increase Learning and Decrease Cheating in the Classroom. Journal of College Teaching and Learning, 2(7), 60-66.

Mujtaba, B. G., Preziosi, R.; \& Mujtaba, L. (April 2004). Adult Learning, Assessment, and the Extraordinary Teacher. Journal of College Teaching and Learning, 1(4), 29-37.

Mujtaba, B. G., \& Mujtaba, L. (March 2004). Diversity Awareness and Management in Adult Education. Journal of College Teaching and Learning, 1(3), 65-75

Mujtaba, B. G., and Sims, R.L. (2006). Socializing Retail Employees in Ethical Values: The Effectiveness of the Formal versus Informal Methods. Journal of Business and Psychology, 21(2), 261-272. Available at: http://www.springerlink.com/content/18r533570827151h/

Mujtaba, B. G., McCartney, Cavico, F.; and DiPaolo, P. (1999). Business Ethics Survey of Managers and Their Associates in the Retail Industry. Journal of Global Competitiveness, 7(1), 427 - 440.

Pelletier, R. A., \& Mujtaba, B. G. (2015). Maximizing Employee Happiness and Well-being: An Examination of Value Creation and Competitive Advantage at Zappos. Advances in Social Sciences Research Journal, 24), 220-232.

Stevens, B., \& Brownwell, J. (2000). Communicating standards and influencing behavior. Cornell Hotel and Restaurant Administration Quarterly. 41(2), 39-43.

Teowkul, K., Seributra, N. J., Sangkaworn, C., Jivasantikarn, C., Denvilai, S, and Muitaba, B. G. (2009). Motivational Factors of Graduate Thai Students Pursuing Master and Doctoral Degrees in Business. RU International Journal, 3(1), 25-56.

Upchurch, R. S. (1998). Ethics in the hospitality industry: An applied model. International Journal of Contemporary Hospitality Management, 10(6), 227-233.

Vallen, G. \& Casado, M. (2000). Ethical principles for the hospitality curriculum. Cornell Hotel and Restaurant Administration Quarterly, 41(2), 44-51.

Whitney, D. L. (1989). The ethical orientations of hotel managers and hospitality students: Implications for industry, education, and youthful careers. Hospitality Education \& Research Journal, 13(3), 187-192.

Yeung, S. (2004). Hospitality ethics curriculum: An industry perspective. International Journal of Contemporary Hospitality Management, 16(4), 253-262.

Yeung, S \& Pine, R. (2003). Designing a hospitality ethics course content from the students' perspective. Journal of Teaching in Travel \& Tourism, 3(2), 19.

Yooyen, A., Pirani, M. and Mujtaba, G. B. (2011). Expectations versus Realities of Higher Education: Gap Analysis and University Service Examination. Contemporary Issues in Education Research, 4(10), 25-35.

Zareen, M., Razzaq, K. and Mujtaba, B. G. (December 2015). Impact of Transactional, Transformational and Laissez-Faire Leadership Styles on Motivation: A Quantitative Study of Banking Employees in Pakistan. Public Organization Review, 15(4), 431549. DOI 10.1007/s11115-014-0287-6.

Ф. Дж. Кавіко, Ph.D., профессор, Південно-східний університет Нова (США);

5. Г. Муджтаба, Ph.D., професор, Південно-східний університет Нова (США).

Інновації у викладанні права, етики та соціальної відповідальності в бізнес-школі: ціннісно-орієнтований підхід до лідерства та сталого розвитку

Суспільство не завжди приймає раціональні рішення, у зв'язку з цим необхідним є створення формальних та неформальних можливостей саморозвитку особистості. Історія свідчить, що висококваліфіковані спеціалісти як в технічних, так і в соціальних галузях приймають нераціональні рішення, що спричинили появу низки негативних наслідків, наприклад, Чорнобильська аварія; лікарська помилка під час операції може призвести до втрати життя пацієнта; інженери проектують та будують мости і споруди, що руйнуються внаслідок прийнятих помилкових інженерних рішень у ході реалізації будівельних проектів. В минулому філософи та вчені перевіряли та доводили різні теоретичні гіпотези, які виявилися помилковими (наприклад, теза, що земля плоска, яка з часом спростувалась). У статті автори приходять до висновку, що найдосвідченіші професіонали здатні помилятись та приймати помилкові рішення. Автори стверджують, що існування даного факту для певної категорії населення є очевидним та зрозумілим, тоді як для інших необхідний певний час для прийняття даного факту та зміни їх парадигми. У зв'язку з цим, громадськість потребує відповідного навчання та самовдосконалення з метою розвитку навиків прийняття більш раціональних та етичних рішень. При цьому необхідним є розгляд проблем правильного вибору (з філософської точки зору) при вивченні дисциплін з етики. У даній статті автори пропонують практичні рекомендації щодо розробки та самостійного вивчення курсу з етики, що охоплюе ключові питання моралі, цінностей, соціальноі відповідальності та сталого розвитку для майбутніх спеціалістів, керівників та лідерів. У статті пояснюється етичний егоїз, релятивізм, утилітаризм та кантівська етика. Методологія даного дослідження заснована на "найкращих практиках", а також 
F. J. Cavico, B. G. Mujtaba. Teaching Law, Ethics, and Social Responsibility in a School of Business: a Value-Driven Approach to Leadership and Sustainability

на власному п'ятдесятирічному досвіді авторів статті. Таким чином, весь зміст та пропозиції, що запропоновані у статті, були апробовані авторами у реальних умовах викладання, що створює базис для їх удосконалення протягом декількох десятиліть. Так, наведені пропозиції та рекомендації можуть бути інтегровані в існуючі навчальні програми факультетами, що викладають курси з етики та інші філософські дисципліни. Автори пропонують впроваджувати запропоновані двадцять три «поради з викладання».

Ключові слова: етика, мораль, викладання, утилітаризм, Кантівська етика, релятивізм, егоїзм, соціальна відповідальність, стійкість.

Manuscript received: 16.10.2018

(C) The author(s) 2018. This article is published with open access at Sumy State University. 